УДК 792.078-027.551(44)(045)

ORCID ID: 0000-0002-3472-1119

Хоптинець Свгенія Андріївна,

аспірантка кафедри організації театральної справи ім. І. Д. Безгіна. Київський національний університет театру, кіно і телебачення імені І. К. Карпенка-Карого.

Хоптинец Евгения Андреевна, аспирантка кафедры организации театрального дела имени И. Д. Безгина. Киевский национальный университет театра, кино и телевидения имени

И. К. Карпенко-Карого, Киев

Yevheniia Khoptynets, Postgraduate Student of Theater Business Organization Department. Kyiv National I. K. Karpenko-Karyi Theatre, Cinema and Television University, Kyiv

\title{
ОРГАНІЗАЦІЙНО-ТВОРЧІ ОСОБЛИВОСТІ ДІЯЛЬНОСТІ ФРАНЦУЗЬКОГО ПРИВАТНОГО ТЕАТРУ «ВАР'СТЕ»
}

Анотація. У статті досліджено історію та головну мету створення французького приватного театру «Вар'єте». Розглянуто діяльність театру «Вар'єте» та його організаційні й творчі особливості. Проаналізовано основні правила, що встановлені театром, а також загальні умови продажу квитків i політику роботи з формуванням ціни продажу квитків. У процесі аналізу виявлено основні принципи організаційно-творчої діяльності французького приватного театру «Вар'єте» і запропоновано застосувати їх у сучасній українській мистецькій практиці.

Ключові слова: приватний театр, діяльність театру «Вар’єте», організаційно-творчі особливості діяльності, репертуар, ціна.

Постановка проблеми та ї̈ актуальність. Театр, як вид сценічного мистецтва, $є$ одним із провідних видів мистецтв, що справляє великий вплив на формування духовних і естетичних цінностей суспільства та збереження національної самобутності. Споконвіку театр був невід'ємною частиною життя людей. Театральне мистецтво відіграє дуже важливу роль і у житті французького суспільства. Постійно та безперервно театр Франції шукає нові шляхи й форми, щоб підкорити публіку, побудувати нові відносини між актором і глядачем. У сучасному світі культурну політику Франції можна взяти за приклад того, як за умов ринкової економіки можна створити досить централізовану систему державного патронату над культурою. Театральне мистецтво Франції є важливою складовою європейської культури і розвивається в органічному зв'язку із суспільно-культурними процесами національного культуротво- рення. Не лише у державному, а й у приватному секторі державна культурна політика Франції формує принципи та засади творчого, фінансово-економічного, кадрового наповнення театральної галузі (L'Express, 2017). Актуальність дослідження полягає в тому, що французький досвід організації театральної справи та розбудови організаційно-творчої діяльності приватних театрів може сприяти покращенню організації театральної справи в українському театральному просторі.

Мета дослідження - розглянути й охарактеризувати творчо-організаційну діяльність приватного театру Парижа «Вар'єте» та проаналізувати, які принципи організаційно-творчої діяльності приватних театрів можна застосувати в сучасній українській мистецькій практиці.

Аналіз останніх досліджень $і$ публікацій. Відповідно до статті «Бум незалежних театрів» (оглядова довідка за матеріалами преси, Інтер- 
нет-мережі та неопублікованими документами 2017-2018 рр.), підготовленої завідувачем відділу наукового аналізу і узагальнення інформації I. Ю. Бурнашовим (2018, с. 2), незалежний театр - це театр приватної форми власності, діяльність якого наближена до західних моделей антрепризи, коли продюсер чи режисер збирає трупу під окремий проєкт, не створюючи постійного колективу. Серед них розрізняють приватні театри (не мають державного фінансування), які можуть бути проєктними (без постійного репертуару) чи на зразок державних - репертуарними.

У «Науковому віснику "Курбасівські читання”» №13 від 2018 року, що видається Національним Центром театрального мистецтва імені Леся Курбаса, у статті Неди Неждани «Міжнародні тенденції у сфері незалежних театральних ініціатив та український феномен» розглянуто діяльність незалежних театрів і форм іiї підтримки в Україні й за кордоном, зокрема у Франції.

Париж є центром театрального життя Франції, де діє понад сімдесят театрів, загальна місткість яких становить понад 35 тисяч місць. Разом із тим місцеве населення і гості Парижа відвідують не лише національні, а й приватні театри, передусім ті, де свого часу були здійснені постановки п'єс відомих драматургів: Жана Кокто, Альбера Камю, Жюля Ромена, Жан-Поля Сартра та інших.

Виклад основного матеріалу. Кажуть, колишня слава паризьких Великих Бульварів вже минула. Але, опинившись тут, повірити в це неможливо. Життя вирує, кафе переповнені, крамнички в пасажах привертають увагу покупців і туристів. Це ж стосується і театрів. У всіх театральних залах на Бульварах постійний аншлаг, іде прем'єра за прем'єрою.

Дешеві ціни на квитки, різноманітність постановок і репертуар, який постійно оновлюється, такими були головні складові успіху бульварних театрів. Простішу публіку розважали з ранку до ночі дешеві балагани, буфонади, цирк. Бульвари ж привертали до себе весь Париж.

Головні ж театри Бульварів, які здобули світову славу, відкрилися на початку XIX століття: театр «Вар'єте» і театр «Порт-Сен-Мартен».

3 приходом в літературу Віктора Гюго, Олександра Дюма, Альфреда де Віньї, Жорж Санд змінилася й французька драматургія. Романтизм прийшов на зміну дешевим і часом вульгарним мелодрамам, які й були основною складовою репертуару бульварних театрів. 3 настанням епохи романтизму театральне життя на Бульварах досягло висот справжнього мистецтва.
Бульварний театр - театр, який грає зрозумілі для всіх побутові п'єси на сучасні сюжети. Вистави мають розважальний характер. Бульварними бувають всі театральні стилі: комедія, драма, водевіль і фарс. Назва бульварних театрів походить від театрів, побудованих у XVII-XVIII століттях на бульварі Тампль у Парижі. Перший бульварний театр відкрив у 1759 році Жан Батист Ніколе, і спочатку називався його іменем. Власник сам давав вистави маріонеток і водночас виступав як актор. 31772 року театр став називатися «королівським», а після революції 1792 року отримав назву Гете, під якою існує і понині (Brunet, Brigitte, 2004).

Можливості бульварних театрів у виборі п'єс були обмежені правом дирекції привілейованого королівського театру Комеді Франсез відбирати найкращі нові п'єси для своєї трупи. Аби залучити більше глядачів, бульварні театри стали орієнтуватися на низький смак обивателів і розважальний репертуар.

Після закону про свободу театрів 1791 року бульварні театри отримали можливість додати в репертуар п'єси Корнеля, Мольєра, Расіна. Але, як і раніше, вистави характеризувалися відчайдушними веселощами і ефектним оформленням. Революція додала до репертуару такі п'єси, як «Смерть Марата» та «Свобода негрів».

На початок XIX століття бульварні театри в основному покладалися на мелодрами. $3 \mathrm{XX}$ століття приміщення паризьких бульварних театрів здебільшого орендуються різними антрепризами, зазвичай для постановки однієї п'єси.

Свого часу театр «Вар'єте» прославився своїми балами-маскарадами, на яких збиралася дуже строката публіка - актриси, студенти, пролетарі, повії. Багато представників знаті й аристократії відвідували вистави мадемуазель Монтансьє. Зрозуміло, інкогніто. Розпорядником балів був Мюзар. Цей скрипаль, диригент і автор танцювальних мелодій вперше поставив канкан. Його станцювали на сцені театру в 1832 році, коли майже весь Париж за стінами театру охопила епідемія холери.

На зміну скандальним танцям прийшов Жак Оффенбах зі своїми оперетами, які пізніше стали класичним музичним жанром. Практично в усіх постановках брала участь знаменита Гортензія Шнайдер, улюблениця Жака Оффенбаха, яка вважала «Вар'єте» своїм домом.

У буквальному перекладі «вар'єте» - різноманітність, суміш. Театр «Вар'єте» розважав публіку, можна сказати, не пропонуючи їй нічого серйозного, але все - для веселощів. 
Почалося все в 1744 році, коли Маргарита Бруне - чотирнадцятирічна вихованка монастиря урсулинок у Бордо - покинула монастир (просто втекла) через молодого актора. Корабель прямував до Америки, але втікачі опинилися на Мартініці, де Маргарита Бруне ніби випадково стала коханкою чи не самого губернатора і не без його участі відкрила в Сан-Домінго магазин одягу. Через певний час вона повернулася в Париж, оселилася у колеги - продавця одягу мадам Монтансьє та взяла собі їі прізвище (Le Théâtre des Variétés).

Мадемуазель Монтансьє відкрила гральний будинок, де бувала золота молодь Парижа. Інтрижка (ймовірна) 3 маркізом де Сен-Конті, сином міністра закордонних справ, - i вона стала керуючою маленьким театром у Версалі, де на неї звернула увагу королева Марія-Антуанетта. Завдання Маргарити Монтансьє - не давати нудьгувати королівському двору. I вона 3 цим блискуче впоралася. Завдяки королю, вона отримала права на театри в Фонтенбло, Сен-Клоді, Марлі, Руані, Канні, Орлеані, Нанті та Гаврі. Більш того, вона побудувала власний театр у Версалі — театр Монтансьє.

Театр було відкрито в 1777 році в присутності короля і королеви. За час свого існування він пережив кілька перейменувань і переїздів. Доля Монтансьє то виносила іiї на вершину популярності, то кидала до в'язниці. Часи близькості з королівським двором (без неї не обходилося жодне свято) змінювалися переслідуваннями, аж до конфіскації майна та ув'язнення. У неї було залізне здоров'я, яке дало їй можливість у 67 років домогтися від уряду компенсації своїх втрат. У 1803 році Наполеон I наказав вигнати театр з Королівського палацу. На думку імператора, класичний репертуар французької комедії не міг бути поряд 3 вульгарними водевільними постановками.

Керівник театру Маргарита Монтансьє разом зі своєю трупою переїхала у власну будівлю, яку спеціально для неї збудував архітектор Селлер'є. Театр «Вар'єте» розташований у другому окрузі Парижа на бульварі Монмартр. Його вузький фасад виконаний у стилі класичного грецького храму і прикрашений кількома рядами струнких іонічних і доричних колон, які підтримують витончений трикутний фронтон.

Засновниця театру Маргарита Монтансье прожила довге життя — вона померла в 1820 році у віці 90 років. Театр же існує й досі.

Організаційно-творчі особливості діяльності театру «Вар'єте». Театр «Вар'єте» розміщується на бульварі Монмартр, 7. Це дуже зручне розта- шування для такого закладу — в кількох хвилинах від метро та автобусних зупинок, а на самому бульварі наявна велика кількість ресторанів, кафе, магазинів. Також поблизу є паркувальні місця для авто.

Театр очолює директор Жан-Мануель Бажен, заступник директора - Ленек Лебрун. У структурі театру виділяють відділ квиткового господарства, у підпорядкуванні якого знаходиться каса; адміністративний відділ (адміністратори, бухгалтерія, охорона і безпека); художньо-постановочну (технічну) частину на чолі з завідувачем (Régisseur Général), якому підпорядковані головний машиніст і заступник головного машиніста, а також відділ преси та реклами (Le Théâtre des Variétés).

Відповідно до інформації, що представлена на сайті театру, здійснення онлайн-покупки квитків цілком захищене завдяки безпечній платіжній системі. Онлайн-бронювання дає змогу вибрати виставу, місця відповідно до плану глядацької зали. Щоб отримати квиток для входу, потрібно роздрукувати підтвердження оплати, прибути до театру за 30 хвилин до початку вистави та надати роздруковані квитки безпосередньо контролеру. Або прибути до театру за 45 хвилин до початку вистави, щоб отримати квитки в квитковій касі, вказавши своє ім'я та номер бронювання.

Також можна забронювати квитки по телефону $з$ понеділка по суботу з 11:00 до 18:00, а в неділю $з$ 12:00 до 16:00.

Продаж квитків здійснюють за правилами, що діють від 1 січня 2002 року. Водночас театр лишає за собою право змінювати ці правила без попереднього повідомлення. Підтверджуючи бронювання квитків і оплачуючи їх, замовник беззастережно приймає умови продажу квитків.

Загальні умови продажу (Le Théâtre des Variétés):

1. Інформацію про ціни і розташування місць представлено в касах театру або іiї повідомляють на вимогу. Всі тарифи можуть бути змінені без попередження.

2. Квитки продають за ціною, яка відображена в касах театру. Театр інформує про знижки та рекламні акції, розміщуючи відповідну інформацію. Глядачі мають повідомити касировіпро бажання скористатися ними.

3. Вказана вартість квитків - це ціна, встановлена на них за умов продажу їх через каси. Для квитків, заброньованих в інший спосіб, крім вартості квитка, стягується плата за бронювання. В окремих випадках за квитки, придбані зі знижкою 
безпосередньо в касі театру, також сплачують плату за бронювання.

4. Театр не пов’язаний із підвищенням цін на квитки, що його можуть здійснити посередники. Для визначення місць враховують лише місце та категорію місця, вказані на квитку.

5. Надруковані квитки є унікальними, і театр не надає дублікати квитків, за винятком випадків викрадення або втрати, підтверджених заявою до поліції, та якщо можна віднайти бронювання. У будь-якому разі, тільки власник квитка має право займати місце в глядачевій залі.

6. Театр гарантує розміщення глядача на вказаному у квитку місці лише до підйому завіси. На початку вистави двері глядачевої зали закривають, а глядачі, які спізнились, можуть зайняти місця на початку другої діiі. Якщо на цю мить їх місця були зайняті іншими глядачами, розміщення відбувається на вільні місця.

7. Вистава починається у час, вказаний у квитках. Анонсовані розклади можуть бути змінені без попередження. Для глядачів, які запізнились на виставу, вартість квитків не відшкодовується.

8. Квитки поверненню не підлягають. Вони дійсні лише на ті вистави, на які їх продали. У разі скасування вистави 3 вини театру, квитки можна обміняти на іншу дату 3 урахуванням наявних місць. Якщо виставу було перервано після того, як відбулася перша половина вистави, квитки ні обміну на іншу дату, ані поверненню не підлягають.

9. Ціни вказані в євро, і театр не приймає платежі в іншій валюті. Витрати, пов'язані з банківськими або поштовими переказами, оплачує глядач. Для країн, що не входять до єврозони, оплата може здійснюватися за допомогою картки Visa або банківських чеків, але винятково в євро.

10. Місця в залі гарантуються тільки після отримання повної оплати за квитки, які видаються лише за умови повної оплати їх ціни, а також оплати будь-яких додаткових витрат. Як виняток, якщо повна оплата не була отримана в день вистави, квитки можуть бути видані за умови внесення гарантійного депозиту, що дорівнює сумі, яка підлягає сплаті.

11. Театр не приймає жодного скасування операції купівлі квитка після оплати місць глядачем. Встановлено, що відносини між театром, який пропонує виставу, вказує ціну місця і час проведення, і глядачем, який купує квиток, незалежно від способу оплати (готівка, чек, кредитна картка, грошовий переказ), є договірними відносинами. Відтак вимагати повернення оплати глядач може лише за умови, якщо театр не виконав своїх зобов'язань.

12. Усі оскарження, незалежно від їх характеру, мають бути представлені в письмовій формі на адресу керівництва театру.

13. Глядач має перевірити кількість придбаних квитків, виданих йому співробітниками театру.

14. Театр залишає за собою право вносити будь-які зміни в порядок і тривалість вистави. 3 іншого боку, театр залишає за собою право скасувати виставу за умови форс-мажорних обставин (погода, страйки, пожежа). В такому разі пропонується відвідати виставу іншого дня.

15. Театр не бере на себе жодної відповідальності за пошкодження речей глядачів, якщо ці речі не були здані на належне зберігання. Глядачі несуть відповідальність за будь-яку пряму чи непряму шкоду, яку вони заподіяли, перебуваючи в театрі.

16. Квитки не дають права на відеозапис вистави. Будь-яку реєстрацію вистави в будь-якій формі, включно із фотографуванням, суворо заборонено. Театр залишає за собою право подати судовий позов, щоб компенсувати завдані збитки.

Використання мобільних телефонів у глядачевій залі (навіть в «авіа» чи безшумному режимі) заборонено.

Купівля квитка на виставу передбачає повне прийняття правил театру, з якими можна ознайомитися на вході до установи або в адміністратора. Кожному, хто не дотримується цих правил, може бути відмовлено у доступі до театру без права вимагати відшкодування вартості квитка.

Керівництво театру залишає за собою право відмовити у вході особам у стані алкогольного сп'яніння або під впливом будь-яких незаконних речовин.

Суворо заборонено вносити в театр зброю, вибухові, легкозаймисті речі, пляшки, контейнери, гострі предмети і взагалі небезпечні об'єкти. Так само суворо заборонено демонструвати у театрі плакати рекламного, політичного, релігійного та ідеологічного характеру.

3 метою гарантування безпеки людей всередині театру може бути здійснено перевірку глядачів. Правопорушники несуть відповідальність за свої дії та будуть піддані судовому переслідуванню.

Відповідно до закону від 1 січня 2008 року в театрі заборонено палити.

Забороняється їсти або пити в приміщенні театру чи проносити напої або будь-яку їжу.

Під час проведення вистави білетери чергують на кожному поверсі приміщення, у фоє чер- 
гує контролер, а в залі — лікар, до яких можна звернутися в разі потреби.

Забороняється розміщувати предмети (пальто, одяг, ключі, програмки) на бильцях бельетажу, балконів та галерей всередині глядацької зали.

Доступ за куліси та у гримерні кімнати акторів відбувається лише за запрошенням. Особи, які бажають отримати автограф, повинні чекати за межами театру.

Театр пропонує особам похилого віку, а також людям 3 хворобами серця чи дихальних шляхів не купувати місця вище другого балкона. Особам, які схильні до запаморочення, рекомендовано резервувати місця в партері. Також в театрі наявні ліфти для людей з обмеженими можливостями.

Театр «Вар'єте» пропонує послугу бронювання для груп - для різноманітних асоціацій, адміністрацій, шкіл, коли замовлення здійснюється на більше ніж десять осіб.

Метою театру є знайти варіанти, що відповідають очікуванням і бажанням глядачів, щоб зробити їх вечір у театрі найкращим.

Театр пропонує додаткові послуги, а саме оренду приміщень, організацію вечорів. Також театр пропонує уроки вокалу, які веде актриса i співачка Сесіль Ноді. Це є одним із шляхів отримання додаткових доходів для театру. Заняття проходять по 3 години на тиждень, а оплата становить 135 євро на місяць (станом на 2019 рік).

Керівництво театру також закликає глядачів підтримати театр фінансово. Завдяки внескам стане можливим доступ до вистав більшої кількості людей, а театр в свою чергу матиме змогу повністю вкладати гроші у виробництво нових театральних постановок.

Для глядачів така підтримка театру також має свої плюси. Фізичні особи отримують податкову знижку у розмірі $66 \%$ від суми внеску в межах $20 \%$ оподатковуваного доходу. Юридичні особи, натомість, отримують зменшення податкових зобов'язань у розмірі $60 \%$ від суми внесків.

У театрі «Вар'єте» дві глядачеві зали: мала зала, розрахована на 120 місць, і велика — на 800 місць. Перед входом до зали $є$ фоє, де розміщена каса для купівлі квитків і віконце, де можна отримати квитки, куплені онлайн, та гардероб.

Ціна квитків залежить від категорії місць та зали. При бронюванні на сайті театру в ціну квитків включається комісія в розмірі від 2 до 5 євро. Категорії місць у великій залі такі:

- місця «золотої» категорії - крісло,

- місця «золотої» категорії - розкладне сидіння,

- перша категорія - крісло,

- перша категорія - ложа,

- перша категорія - розкладне сидіння,

- друга категорія - крісло,

- друга категорія - банкетка,

- друга категорія - розкладне сидіння,

- третя категорія та

- четверта категорія - банкетка.

А якщо театр дає вистави для дітей у великій залі, то назви категорій змінюються для заохочення маленьких глядачів. Наприклад, для вистави «Книга Джунглів» категорії місць отримують назви за іменами героїв: ложа Багіри, ложа Балу, ложа Мауглі, ложа Шер-Хана. Також на цю виставу пропонують місця «золотої» категорії (крісла, розкладні сидіння), першої категорії (крісла, ложа, розкладні сидіння), другої категорія (крісла, ложа) і третьої категорії.

Окрім того, що ціни залежать від категорій місць, вони також залежать від вистави, яку пропонують глядачам: комедії, опери (див. Таблицю 1), вистави для дітей (див. Таблицю 2).

Ціна квитків при бронюванні на сайті театру «Вар'єте» на вистави у 2019 році

Таблиия 1.

\begin{tabular}{|c|c|c|}
\hline \multirow{3}{*}{ Категорії місць } & \multicolumn{2}{|c|}{ Назва вистави } \\
\hline & Комедія «Один з десяти» & $\begin{array}{c}\text { Комедія «Найкрасивіший } \\
\text { у всьому світі» }\end{array}$ \\
\hline & \multicolumn{2}{|c|}{ Ціна (+ сума включеної комісії) } \\
\hline Єдина категорія (камерна сцена) & 20 євро (+ 2 євро) & \\
\hline місця «золотої» категорії - крісла & & 63 євро (+ 5 євро) \\
\hline перша категорія - крісло & & 53 євро (+ 5 євро) \\
\hline перша категорія — ложа & & 50 євро (+ 5 євро) \\
\hline друга категорія — крісло & & 43 євро (+ 5 євро) \\
\hline друга категорія - банкетка & & 43 євро (+ 5 євро) \\
\hline друга категорія - розкладне сидіння & & 30 євро (+ 5 євро) \\
\hline третя категорія — банкетка & & 20 євро (+ 5 євро) \\
\hline четверта категорія - банкетка & & 20 євро (+ 5 євро) \\
\hline
\end{tabular}


Таблиия 2.

Ціна квитків при бронюванні на сайті театру «Вар'єте» на дитячу виставу «Книга Джунглів» у 2019 році

\begin{tabular}{|l|c|}
\hline \multicolumn{1}{|c|}{ Категорії місць } & $\begin{array}{c}\text { Ціна } \\
\text { (комісія відсутня) }\end{array}$ \\
\hline ложа Багіри & 49,75 євро \\
\hline ложа Балу & 49,75 євро \\
\hline ложа Мауглі & 49,75 євро \\
\hline ложа Шер-Хана & 49,75 євро \\
\hline $\begin{array}{l}\text { місця «золотої» категорії- } \\
\text { крісла }\end{array}$ & 38 євро \\
\hline перша категорія — крісло & $30 є в р о ~$ \\
\hline перша категорія — ложа & 26 євро \\
\hline друга категорія — ложа & 16 євро \\
\hline третя категорія & 14 євро \\
\hline
\end{tabular}

У ложі Багіри, Балу, Мауглі й Шер-Хана місця продають за спеціальною програмою - одразу по чотири, за 199 євро. Преміальна пропозиція передбачає, крім квитків на виставу CD із музикою фільму, «солодкі» подарунки, зустріч і фото глядачів із акторами вистави та афішу вистави з автографами.

Також на дитячу виставу «Книга Джунглів» для глядачів театр пропонує акцію. Блок із чотирьох квитків у вказані ложі можна придбати за промоційною ціною у 140 євро. Відтак ціна одного квитка становить 35 євро (на 14,75 євро менше), а загальна економія - 59 євро.

Ціна квитків у малій залі театру «Вар'єте» залежить від вистави, а самі місця глядачевої зали не розподілено на категорії. Ціни квитків варіюються від 14 до 16 євро (в цю ціну включено і комісію за бронювання від 1 до 2 євро).

Репертуар театру «Вар'єте» на сезон становлять три або чотири вистави. Всі вистави мають розважальний характер. Також завжди поряд із виставами для дорослих $є$ вистава-мюзикл для дітей (яка привертає увагу і дорослих глядачів). Період прокату вистави зазвичай триває не більше року. Виставу грають доти, доки не зменшується відвідуваність.

Крім того, що театр «Вар'єте» грає власні постановки, він приймає на своїй сцені інші колективи. Зокрема, тут гастролювали театр Сен-Жорж, театр Жимназ, а також Паризька школа музичної комедії. Театральне життя на бульварах Парижа вирує, в театрі «Вар'єте» - завжди аншлаги, адже якщо не всі квитки продаються через касу, театр працює через посередників, які продають квитки за акційними цінами - по 10 євро.
Доступні ціни на квитки, різноманітність постановок і репертуар, який постійно оновлюється, — це головні складові успіху театру «Вар'єте».

Виходячи з розглянутого вище, можна виокремити основні принципи організаційно-творчої діяльності театру «Вар'єте», якими заклад керується, а саме інформованість, що передбачена умовами продажу та правилами, котрі розміщені як на сайті театру, так і на вході до театру та в адміністратора; принцип загальнодоступності, який включає доступні ціни на квитки, адже діють акції, купівлю квитків можна здійснювати онлайн, бронювати по телефону або купувати в касі театру; крім цього, театр оснащений ліфтом, що дає змогу відвідувати його людям 3 обмеженими можливостями, різноманітність, підтверджена тим, що у репертуарі театру наявні вистави як для дорослих, так і для дітей (більш того, дитячі місця мають назви відповідно до дійових осіб вистави), а оскільки вистави в театрі в прокаті не більше року, то глядачам пропонується постійне їх оновлення.

Висновки. Культурна політика сучасної Франції полягає не лише в тому, що держава надає кошти на розвиток культури та мистецтва. За державною фінансовою підтримкою стоїть єдина скоординована та концептуально продумана політика, що базується на певних принципових засадах. Розширення сфери підтримки для держави передусім означало активну підтримку з боку держави для французьких культурних індустрій, в тому числі комерційних.

Для України є показовим цей досвід державної підтримки французького театрального мистецтва. Значну частину фінансування театрів як державних, так і недержавних забезпечує держава. Держава здійснює фінансування різних форм власності, а саме - це державні, приватні, муніципальні, пайові та інші -через свої регіональні культурні центри, які функціонують у кожному департаменті. Український приватний театр має потенціал для розвитку, і досвід організаційно-творчої діяльності приватних театрів Парижа бажано взяти до уваги, адже застосування таких простих принципів, що їх використовує театр «Вар'єте», а саме загальнодоступність (мається на увазі, що не кожен український театр може похвалитись приміщенням, пристосованим для людей $з$ обмеженими можливостями), чи проведення акцій для придбання квитків, що також сприяє більшій відвідуваності театру, чи наявність правил, що відразу регулює відносини між театром та глядачем і зменшує виникнення конфліктних ситуацій. Театр «Вар'єте» поєднує репертуарну 
та проєктну політику, оскільки вистави граються не більше року; отож як пілотний проєкт таке поєднання може стати вдалою спробою й для українського театру.

\section{Бібліографія}

Бурнашов, І. Ю. Бум незалежних театрів (оглядова довідка за матеріалами преси, Інтернету та неопублікованими документами 2017-2018рp.). МІНІСТЕРСТВО КУЛЬТУРИ УКРАЇНИ НАЦІОНАЛЬНА БІБЛІОТЕКА УКРАЇНИ ІМЕНІ ЯРОСЛАВА МУДРОГО ІНФОРМАЦІЙНИЙ ЦЕНТР 3 ПИТАНЬ КУЛЬТУРИ ТА МИСТЕЦТВА / ДЗК. 2018. Вип. 7/4. Відновлено 3: http://nlu.org.ua/storage/files/ Infocentr/Tematich_ogliadi/2018/teatr18.pdf

Неждана, Н. Міжнародні тенденції у сфері незалежних театральних ініціатив та український феномен. Науковий вісник «Курбасівські читання». 2018. №13. Відновлено 3: http://kurbas.org.ua/projects/almanah13/kurbasivski13.pdf

Brunet, Brigitte (2004). Le Théâtre de Boulevard. Paris: Nathan.

Le théâtre privé fait pression pour accéder aux scènes publiques. L'Express. 13.09.2017. Відновлено 3: https://www.lexpress. fr/actualites/1/culture/le-theatre-prive-fait-pression-pouracceder-aux-scenes-publiques_1943106.html

Conditions générales de vente. Le Théâtre des Variétés. Відновлено 3: http://www.theatre-des-varietes.fr/content/ conditions-generales-de-vente.html

L'Equipe. Le Théâtre des Variétés. Відновлено 3: http://www. theatre-des-varietes.fr/content/equipe.html L'histoire du théâtre. Le Théâtre des Variétés. Відновлено 3: https://www. theatre-des-varietes.fr/theatre/histoire/

\section{References}

Burnashov, I. (2018). The boom of independent theaters: A review of the press, the Internet and unpublished documents in 2017-2018). MINISTRY OF CULTURE OF UKRAINE YAROSLAV WISE NATIONAL LIBRARY OF UKRAINE INFORMATION CENTER ON CULTURE AND ARTISTICS. Publication. 7/4. Retrieved from: http://nlu.org. ua/storage/files/Infocentr/Tematich_ogliadi/2018/teatr18. pdf. [in Ukrainian]

Nezhdana, N. (2018). International trends in the field of independent theatrical initiatives and the Ukrainian phenomenon. Scientific Bulletin «Kurbas Readings». №13. Retrieved from: http://kurbas.org.ua/projects/almanah13/ kurbasivski13.pdf [in Ukrainian]

Brunet, Brigitte (2004). The Boulevard Theater. Paris: Nathan. [in French]

Private theater lobbies for access to public stages. L'Express. Retrieved from: https://www.lexpress.fr/actualites/1/culture/ le-theatre-prive-fait-pression-pour-acceder- aux-scenespubliques_1943106.html [in French]

General conditions of sale. Le Théâtre des Variétés. Retrieved from: http://www.theatre-des-varietes.fr/content/conditionsgenerales-de-vente.html [in French]

The team. Le Théâtre des Variétés. Retrieved from: http://www. theatre-des- varietes.fr/content/equipe.html [in French]

The history. Le Théâtre des Variétés. Retrieved from: https:// www.theatre-des-varietes.fr/theatre/histoire/ [in French]

\section{Yevheniia Khoptynets}

Abstract. The article explores the history and main purpose of creating a French private Theater «Variety». The activities of this Theater and its organizational and creative features are considered. The basic rules established by the theater are analyzed, as well as the general conditions of ticket sales and the policy to make with the formation of the ticket price. The analysis revealed the basic principles of organizational and creative activities of the French private theater «Variety» and proposed to apply in the modern Ukrainian art practice.

Keywords: private theater, Variety Theater activities, organizational and creative features of the activity, repertoire, price.

\section{Хоптинец Евгения Андреевна}

Аннотация. В статье исследована история и главная цель создания французского частного театра «Варьете». Рассмотрена деятельность театра «Варьете» и его организационные и творческие особенности. Проанализированы основные правила, установленные театром, а также общие условия продажи билетов и политика формирования цены продажи билетов. В процессе анализа выявляются основные принципы организационно-творческой деятельности французского частного театра «Варьете» и предлагается применить их в современной украинской художественной практике.

Ключевые слова: частный театр, деятельность театра «Варьете», организационно-творческие особенности деятельности, репертуар, цена. 